PM we started passed through Moravia \& on to Soap Creek \& halted to sec Rev H. P. Morrison an old comrade in the army, found him well \&: doing finely after a social interview we started on crosed Sope [Soap] Creek \& on to Unionville. there called on Doctor Sawyer our first Regimental surgeon $\&$ had a pleasant interview. Saw Joel Staley there an old friend then onward through Unionville to Drakeville halted a short time \& passed on $1 \frac{1}{2}$ miles east \& camped for the night.

Wednesday, June 26 . Beautifull day but warm with showers at night at a little after daylight we started from camp $11 / 2$ miles east of Drakeville Davis Co Iowa \& we drove into Bloomfield Co Seat \& took breakfast with my Nephew John Campbell \& spent a pleasant hour with them then drove to Mr. Kirk England's near Pulaski \& spent a pleasant interview \& took dinner with them he married Brother Augustus' daughter Maria. we left \& called a short time to see Elisha L. Kirk in Pulaski \& then on \& called an hour on my Eldest Sister's Daughter Mrs. Henry Tootwiler \& then on to Brother Augustus's \& put up with them for the night we found my friends (sentence unfinished).

Thursday, June 27; 187\%. Variable warm at $\tau$ Oc A.M. we started from Brother Augustus's \& passed round to Troy spent an hour in the village \& then started for home on through Lebanon ${ }^{13}$ \& Pittsburgh $^{14}$ forded the Des Moines River there \& arrived home at 12 Oc noon \& thank the good Lord found my family well. After dinner I hitched up \& took Jesse W. Hambleton over the river called a short time at my Son's \& then went on with Mr. Hambleton to Mr. Gaggses to his Barn Raising \& assisted a short time \& then returned to my son's \& then on home thank the Lord for a temporal home as I pass to a heavenly \& an eternal home which by the grace of God I hope to gain.

13A village, now abancloned, then located at the cross roads or common cormers of Sections 1 and 2 , Jackson Township, and 35 and 36 , Chequest Township, Van Buren County, six miles west of the county seat. Keosauqua.

14 A town. now abandoned, then located on the west bank of the Des Moines River, in Section 27. Van Buren Township, Van Buren County, three miles nortliwest of Keosauqua.

\title{
DES MOINES TO TOPEKA MAIL ROUTE ESTABLISHED
}

A bill has passed the House of Representatives establishing a new mail route from this city to Topeka, Kansas, by way of Saint Joseph. This route is much needed by the entire people of Iowa, and we hope to be able to chronicle its active operation soon.-The Iozva Tri-Weely Citizen, Des Moines, February 6, 1858. (In the Newspaper Division of the Historical, Memorial and Art Department of Iowa.) 
Copyright of Annals of Iowa is the property of State of Iowa, by \& through the State Historical Society of Iowa and its content may not be copied or emailed to multiple sites or posted to a listserv without the copyright holder's express written permission. However, users may print, download, or email articles for individual use. 